\title{
GLYCOPYRROLATE METHOBROMIDE 2. COMPARISON WITH ATROPINE SULPHATE IN ANAESTHESIA
}

\author{
KoFI A. Oduro ${ }^{\circ}$
}

Glycopynolate is a synthetic quaternary ammonium compound which is an anticholinergic agent. It has been used to control gastric acidity since its introduction as ROBINOL ${ }^{(}$by A.H. Robins Company in 1960. Most previous clinical reports have related to its use in the management of peptic ulcers and other disorders associated with gastric hyperacidity and it appears that the literature on its value in anaesthetic practice is scanty.

Glycopyrrolate appears to be a potent anticholinergic drug. Being a quaternary ammonium compound, it cannot pass readily through the blood brain barrier. It is said to have minimal side effects and a long duration of action. As an anticholinergic agent, it has among other properties the ability to cause dryness of the mouth and pharynx. It appears to be free from side effects.

The present double blind study was designed to compare the clinical usefulness of glycopyrollate with atropine as a pre-anaesthetic medication in adults; and to compare the relative effectiveness of glycopyrrolate and atropine in anatagonizing the muscarinic effects of neostigmine methylsulphate given to reverse neuromuscular blockade.

\section{METHODS}

A generally randomized sample of 98 patients made up of 32 males and 66 females with ages ranging from 16 to 73 years were included in this study. They were undergoing elective intra-abdominal operations under general anaesthesia. There were 49 patients in each of the glycopyrrolate and the atropine groups. The drugs were provided in identical bottles, each bottle bearing a special serial number for later identification. Table I shows the age distribution of the two groups of patients.

Table II shows the distribution by type of operation and the number of patients in each group. All the patients for cholecystectomy were given a premedication intramuscularly consisting of meperidine 50 to $100 \mathrm{mg}$ (the majority receiving the lower dosage) and either atropine $0.4 \mathrm{mg}$ or glycopyrrolate $0.2 \mathrm{mg}$, from the coded supply, 45 minutes to one hour before operation. Anaesthesia was induced with thiopentone 2.5 per cent in a dose ranging from $250 \mathrm{mg}$ to $500 \mathrm{mg}$, most patients receiving the lower dose range, and was then maintained with nitrous oxide and oxygen in the semi-closed circle absorber system. Intravenous meperidine 10 to $20 \mathrm{mg}$ was administered intermittently to provide analgesia. Dimethyl tubocurarine iodide was the muscle relaxant for all the 98 patients. To block the

"From the Department of Anaesthesia, University of Saskatchewan and University Hospital, Saskatoon, Sask. Present address: Department of Anaesthesia, University of Ghana Medical School, P.O. Box 4236, Accra, Ghana. 
TABLE I

Ages of Patients

\begin{tabular}{lccccccc}
\hline \hline & \multicolumn{3}{c}{ Atropine } & & \multicolumn{3}{c}{ Glycopyrrolate } \\
\cline { 2 - 4 } \cline { 7 - 9 } & No. & Mean & S.D. & & No. & Mean & S.D. \\
\hline Male & 12 & 49.3333 & 12.5505 & & 20 & 48.9000 & 15.0574 \\
Female & 37 & 42.4167 & 12.4289 & & 29 & 43.4138 & 13.3404 \\
Male and Female & 49 & 44.1458 & 12.6911 & & 49 & 45.6531 & 14.1768 \\
\hline
\end{tabular}

TABLE II

\begin{tabular}{lcc}
\hline \hline & Atropine & Glycopyrrolate \\
\cline { 2 - 3 } & No. of patients & No. of patients \\
\hline Cholecystectomy & 36 & 39 \\
Gastric and Duodenum & 12 & 8 \\
Cholecystectomy and Hiatus Hernia & 1 & 1 \\
Carcinoma of Colon & - & 49 \\
Total & 49 & - \\
\hline
\end{tabular}

muscarinic effects of neostigmine methylsulphate, double the dose of the same unknown anticholinergic used for the premedication was administered intravenously five minutes prior to neostigmine.

The other patients had morphine 10 to $15 \mathrm{mg}$ and the unknown anticholinergic for premedication. Dimethyl tubocurarine iodide was again the muscle relaxant used. Anaesthesia and analgesia were maintained with nitrous oxide, oxygen and methoxyflurane in a semi-closed circle system with the absorber in circuit. Nine patients in the atropine group and seven in the glycopyrrolate group had methoxyflurane. In one patient in the atropine group, anaesthesia was maintained by halothane. Once again, double the premedication dose of the unknown anticholinergic was given five minutes prior to administration of neostigmine for the reversal of the muscle relaxant.

Parameters monitored were pulse rate, blood pressure, oral temperature, the electrocardiogram and the size of the pupils. These were recorded before premedication, 45 minutes to 60 minutes after premedication, before induction, after induction, at frequent intervals during the operation, before and for five minutes after the intravenous administration of the anticholinergic drug at the end of operation and before and for five minutes after neostigmine. The pharynx was suctioned before and after extubation or, when the trachea was not extubated, before the patient left the operating room. The amount of saliva suctioned through the transparent tube was assessed clinically, comparing the quantity with what, from one's experience, was usually obtained from atropine and neostigmine reversal. 


\section{Results}

\section{Pharyngeal secretions}

The mouth and pharynx were assessed as moist or dry before premedication was administered and prior to induction. There was no significant difference in the state of the pharynx between the two groups, before premedication was given.

The state of the pharynx before induction in the two groups is shown in Table III. The results in the two groups are not significantly different. Glycopyrrolate $0.2 \mathrm{mg}$ or atropine $0.4 \mathrm{mg}$ given intramuscularly for premedication produce the same antisialogogue effect on the pharynx. This is consistent with the findings of Wyant and Kao. ${ }^{1}$

The effect of each anticholinergic agent in antagonizing the salivary stimulating effect of neostigmine was assessed five minutes after neostigmine administration as:

(a) Dry pharynx

(b) Less than average secretions

(c) Average secretions (as after atropine and neostigmine)

(d) Excessive secretions.

Table IV gives the results of this study. Glycopyrrolate is significantly superior to atropine in antagonizing the salivation stimulated by neostigmine. Ramamurthy, Ylagan and Winnie ${ }^{2}$ also observed that in their group of patients reversed with a glycopyrrolate-neostigmine mixture, secretions were virtually non-existent. The method of evaluating the volume of secretions in this study has many drawbacks compared with the more accurate method used by Wyant and Dobkin ${ }^{3}$ and more recently by Wyant and Kao. ${ }^{1}$ However, with an intubated trachea, their method would have been perhaps more difficult to employ.

\section{Effects on Pulse Rate}

Changes in pulse rate were studied and compared at specific time intervals. These were:

1. Forty-five minutes to one hour after premedication, or before induction.

2. Two minutes and five minutes after the intravenous administration of the anticholinergic agent (atropine $0.8 \mathrm{mg}$ or glycopyrrolate $0.4 \mathrm{mg}$ ).

3. At two minutes and five minutes after the intravenous administration of neostigmine methylsulphate $2.5 \mathrm{mg}$.

4. Bradycardia within one hour of cessation of anaesthesia.

The difference between the mean pulse rates of the two groups before premedication was administered was not significant $(t=0.6 \mathrm{p}>0.5)$.

\section{Pulse rate changes 45 minutes to 60 minutes after premedication}

While the mean changes in pulse rate from premedication level for each group were significant (for atropine, $\mathrm{t}=4.4,48 \mathrm{df}, \mathrm{p}<0.01$, and for glycopyrrolate, $t=3.0,47 \mathrm{df}, \mathrm{p}<0.01$ ), they were nearly the same for each treatment group. Table $\mathrm{V}$ presents the incidence of pulse rate changes for the intervals indicated. 
TABLE III

State of Pharynx Before Induction

\begin{tabular}{lcc}
\hline & Atropine & Glycopyrolate \\
\hline Dry & 34 & 37 \\
Moist & 15 & 12 \\
Total & 49 & 49 \\
\hline$\chi^{2}=0.4602(<0.5)$. & &
\end{tabular}

TABLE IV

$x^{2}=20.8850(P<0.005)$

\begin{tabular}{lccc}
\hline \hline & Atropine & Glycopyrrolate & Total \\
\hline Dry & 7 & 18 & 25 \\
Less than Av. & 6 & 17 & 23 \\
Av. & 22 & 11 & 33 \\
Excessive & 14 & 3 & 17 \\
Total & 49 & 49 & 98 \\
\hline
\end{tabular}

Results of antisialogogue action after neostigmine challenge.

TABLE $\mathrm{V}$

Incidence of Pulse Rate Change from Observation at PremediCation to that Approximately 60 Minutes Later

\begin{tabular}{lcrr}
\hline \hline & & A & G \\
\hline \multirow{2}{*}{ Increase } & $31+$ & 8 & 7 \\
& $21-30$ & 7 & 4 \\
No change & $11-20$ & 10 & 9 \\
Decrease & \pm 10 or fewer & 19 & 19 \\
Not stated & $11-20$ & 4 & 8 \\
\hline A = Atropine. & $21+$ & 0 & 2 \\
G $=$ Glycopyrrolate. & & 1 & - \\
\end{tabular}

TABLE VI

Incidence of Pulse Rate Change from Observation Immediately Before Administration of Anticholinergic to Observation at Two and at Five Minutes Later

\begin{tabular}{|c|c|c|c|c|c|}
\hline & & \multicolumn{2}{|c|}{ Two minutes } & \multicolumn{2}{|c|}{$\begin{array}{l}\text { Five minutes } \\
\mathrm{A}\end{array}$} \\
\hline Increase & $\begin{array}{l}31+ \\
21-30 \\
11-20\end{array}$ & $\begin{array}{r}19 \\
15 \\
8\end{array}$ & $\begin{array}{r}5 \\
14 \\
15\end{array}$ & $\begin{array}{r}18 \\
18 \\
5\end{array}$ & $\begin{array}{r}27 \\
8 \\
7\end{array}$ \\
\hline No change & \pm 10 or fewer & 5 & 13 & 5 & 5 \\
\hline Decrease & $\begin{array}{l}11-20 \\
21-30 \\
31+\end{array}$ & 二 & E & 二 & E \\
\hline Not Stated & & 2 & 2 & 3 & 2 \\
\hline
\end{tabular}


Pulse rate changes after the intravenous administration of the anti-cholinergic

The incidence of pulse rate changes are shown in Table VI, which suggests that, at two minutes, the glycopyrrolate group exhibited a lesser degree of increase in pulse rate. However, by the five-minute observation, it appears that the greater increase is associated with glycopyrrolate. To examine this finding, the distribution of the patients with pulse rates greater than 100 beats per minute at the five-minute observation is presented in Table VII. This shows that the higher rates are associated with the atropine group. This finding and the results of the two-minute observation are consistent with the observations of Ramamurthy, Shaker and Winnie ${ }^{4}$ that glycopyrrolate produces less tachycardia than atropine.

For completeness, the results before the anticholinergic, and two minutes and five minutes after the anticholinergic were subjected to an analysis of variance for a 2 (DRUGS)-by-3 (TIMES) factorial design with repeated measures across the TIMES factor. The summary is displayed in Table VIII and indicates that the mean pulse rates are significantly different only at the two-minute observation.

Pulse rate changes after the intravenous administration of neostigmine $2.5 \mathrm{mg}$

The incidence of changes in pulse rates are displayed in Table IX and indicate that the greater decreases in pulse rate are associated with atropine, at least at the two-minute observation. For the absolute pulse rates, an analysis of variance of the same type as described above is summarized in Table $\mathrm{X}$ and indicates that the mean pulse rates at both two minutes and five minutes are greater for the glycopyrrolate group, a result also consistent with the finding of Ramamurthy, Shaker and Winnie. ${ }^{4}$

There does not appear to be a statistically significant relationship between the two-minute change in pulse rate after administration of the anticholinergic and the two-minute change after neostigmine (for atropine, $r=0.20, p>0.10$, and for glycopyrrolate $\mathrm{r}=0.24, \mathrm{p}>0.10$ ).

\section{Post-operative bradycardia}

Within the first hour of cessation of anaesthesia 14 patients in the atropine group had developed bradycardia requiring further intravenous injection of the same anticholinergic drug, while only eight patients in the glycopyrrolate group had developed bradycardia that required treatment. This is not significantly different $\chi^{2}=2.11(0.1<\mathrm{P}<0.25)$.

\section{Blood Pressure Changes}

There was no significant difference in the blood pressure changes in the two groups.

\section{Bradycardia During Operation}

Three patients in each group required further intravenous anticholinergic during operation, for treatment of sinus bradycardia.

In the atropine group the tracheae of five patients were not extubated because of inadequate ventilation. Only one in the glycopyrrolate group left the operating room with the tracheal tube in place. 
TABLE VII

Distribution of Absolute Pulse Rates Observed as Greater than 100 Beats per Minute at Five Minutes Following AdMinistration OF ANTICHOLINERGiC

\begin{tabular}{ccc}
\hline \hline & Atropine & Glycopyrrolate \\
Greater than 100 & 20 & 28 \\
\hline $101-110$ & 3 & 9 \\
$111-120$ & 8 & 10 \\
$121-130$ & 1 & 5 \\
$131-140$ & 5 & 4 \\
$141-150$ & 2 & 0 \\
$151+$ & 1 & 0 \\
\hline
\end{tabular}

TABLE VIII

Analysis of Variance Summary of Pulse Rates of the Atropine and Glycopyrrolate Treatment Groups Before Anticholinergic and Two and Five Minutes Later

\begin{tabular}{|c|c|c|c|c|}
\hline Source & SS & $\mathrm{df}$ & MS & $\mathrm{F}$ \\
\hline $\begin{array}{l}\text { Drugs } \\
\text { Subj w/i groups }\end{array}$ & $\begin{array}{r}154.83 \\
68375.56\end{array}$ & $\begin{array}{r}1 \\
90\end{array}$ & $\begin{array}{l}154.83 \\
759.73\end{array}$ & $<1$ \\
\hline $\begin{array}{l}\text { Times } \\
\text { Drug } \times \text { Times } \\
\text { Times } \times \text { subj } w / \text { i groups }\end{array}$ & $\begin{array}{r}47357.97 \\
1468.78 \\
17938.16\end{array}$ & $\begin{array}{r}2 \\
2 \\
180\end{array}$ & $\begin{array}{r}23678.98 \\
734.39 \\
99.66\end{array}$ & $\begin{array}{r}237.61 \\
7.37\end{array}$ \\
\hline $\begin{array}{l}\text { Simple main effects } \\
\text { Drugs Before Anticholinergic } \\
\text { Drugs at } 2 \text { min } \\
\text { Drugs at } 5 \text { min } \\
\text { Within cell }\end{array}$ & $\begin{array}{r}115.13 \\
1473.13 \\
35.13 \\
86313.69\end{array}$ & $\begin{array}{r}1 \\
1 \\
1 \\
270\end{array}$ & $\begin{array}{r}115.13 \\
1473.13 \\
35.13 \\
319.68\end{array}$ & $4.61 \stackrel{<1}{<<<0.05)}$ \\
\hline \multicolumn{5}{|c|}{ Table of means } \\
\hline $\begin{array}{l}\text { Atropine } \\
\text { Glycopyrrolate }\end{array}$ & $\begin{array}{l}\text { inergic } \\
5\end{array}$ & & 6 & $\begin{array}{c}\text { Five minutes } \\
104.3 \\
105.5\end{array}$ \\
\hline
\end{tabular}

TABLE IX

Incidence of Pulse Rate Changes from Observation Immediately Before Administration of ANTICHOLINERGic to Observation at Two and at Five Minutes Later

\begin{tabular}{|c|c|c|c|c|c|}
\hline & & \multicolumn{2}{|c|}{ Two minutes } & \multicolumn{2}{|c|}{ Five minutes } \\
\hline & & A & $\mathrm{G}$ & A & G \\
\hline Increase & $\begin{array}{l}31+ \\
21-30 \\
11-20\end{array}$ & $\begin{array}{r}- \\
1\end{array}$ & $\frac{1}{2}$ & $\frac{1}{-}$ & - \\
\hline No Change & \pm 10 or fewer & 20 & 33 & 7 & 12 \\
\hline Decrease & $\begin{array}{l}11-20 \\
21-30 \\
31+\end{array}$ & $\begin{array}{r}12 \\
6 \\
4\end{array}$ & $\begin{array}{r}10 \\
1 \\
2\end{array}$ & $\begin{array}{r}9 \\
11 \\
16\end{array}$ & $\begin{array}{r}11 \\
8 \\
16\end{array}$ \\
\hline Not Stated & & 4 & - & 5 & 一 \\
\hline
\end{tabular}

A = Atropine.

$\mathrm{G}=$ Glycopyrrolate. 
TABLE $X$

Analysis of Variances Summary of Pulse Rates of Atropine and Glycopyrrolate Treatment Groups Before Neostigmine and Two and Five Minutes Later

\begin{tabular}{|c|c|c|c|c|}
\hline Source & SS & df & MS & $\mathrm{F}$ \\
\hline $\begin{array}{l}\text { Drugs } \\
\text { Subj w/i groups }\end{array}$ & $\begin{array}{r}2532.59 \\
61427.93\end{array}$ & $\begin{array}{r}1 \\
90\end{array}$ & $\begin{array}{r}2532.59 \\
682.53\end{array}$ & 3.71 \\
\hline $\begin{array}{l}\text { Times } \\
\text { Drug } \times \text { Times } \\
\text { Times } \times \text { subj w } / \text { i groups }\end{array}$ & $\begin{array}{r}33255.14 \\
622.00 \\
33618.32\end{array}$ & $\begin{array}{r}2 \\
2 \\
180\end{array}$ & $\begin{array}{r}16627.57 \\
311.00 \\
180.77\end{array}$ & $\begin{array}{r}89.03 \\
1.67\end{array}$ \\
\hline $\begin{array}{l}\text { Simple main effects } \\
\text { Drugs Before Neostigmine } \\
\text { Drugs at } 2 \mathrm{~min} \\
\text { Drugs at } 5 \mathrm{~min} \\
\text { Within cell }\end{array}$ & $\begin{array}{r}77.75 \\
1444.88 \\
1632.13 \\
95046.25\end{array}$ & $\begin{array}{r}1 \\
1 \\
1 \\
270\end{array}$ & $\begin{array}{r}77.75 \\
1444.88 \\
1632.13 \\
352.02\end{array}$ & $\begin{array}{c}<<1 \\
4.10(\mathrm{p}<0.05) \\
4.64(\mathrm{p}<0.05)\end{array}$ \\
\hline \multicolumn{5}{|c|}{ Table of means } \\
\hline $\begin{array}{l}\text { Atropine } \\
\text { Glycopyrrolate }\end{array}$ & $\begin{array}{c}\text { Before } \\
\text { Neostigmine } \\
105.58 \\
107.43\end{array}$ & & $\begin{array}{l}\text { inutes } \\
47 \\
41\end{array}$ & $\begin{array}{l}\text { Five minutes } \\
76.23 \\
84.67\end{array}$ \\
\hline
\end{tabular}

Three patients in the glycopyrrolate group developed brief periods of pulsus bigeminus which was, perhaps, unconnected with the anticholinergic drug. No patient in either group complained of blurred vision or disturbances of accommodation. None found the dryness of the pharynx unbearable.

\section{SUMMARY}

A double blind study of 98 patients was undertaken to compare the clinical usefulness of atropine and glycopyrrolate for pre-anaesthetic medication and their relative effectiveness in antagonizing the muscarinic effects of neostigmine methylsulphate given to reverse neuromuscular blockade. Intramuscular administration of atropine $0.4 \mathrm{mg}$ or of glycopyrrolate $0.2 \mathrm{mg}$ produced the same degree of dryness of the pharynx. However, glycopyrrolate was found to be a more potent antagonizer of the increased salivation induced by neostigmine. By intramuscular administration, both drugs produced the same degree of tachycardia, although atropine tended to cause no change in the pulse rate or even to produce bradycardia in a greater number of patients. Administered intravenously, atropine produced a more significant tachycardia in a large number of patients prior to neostigmine administration, although the protection against a decreased pulse rate from neostigmine is greater in those patients who received glycopyrrolate. It would appear, therefore, that glycopyrrolate is more effective in antagonizing the muscarinic effects of neostigmine methylsulphate.

\section{RÉSUMÉ}

Ce travail avait pour but d'établir la valeur clinique de l'atropine et du glycopyrrolate en pré-médication, ainsi que d'étudier leur efficacité relative à contrecarrer les effets muscariniques de la néostigmine employée pour renverser la curarisation. Quatre vingt dix huit malades ont été inclus dans cette étude à double-insu. 
Une injection intra-musculaire de $0.4 \mathrm{mg}$ d'atropine ou de $0.2 \mathrm{mg}$ de glycopyrrolate produisent le même degré de sécheresse du pharynx. Nous avons cependant trouvé que le glycopyrrolate était un meilleur inhibiteur de la salivation induite par une injection de néostigmine.

Après administration intra-musculaire, les deux agents produisent le même degré de tachycardie, mais on a observé que la fréquence n'était pas modifiée, ou même qu'elle était ralentie chez un plus grand nombre de patients ayant eu de l'atropine.

Par voie intra-veineuse, avant administration de néostigmine, l'atropine produisait plus de tachycardie, bien que la protection contre la bradycardie induite par la prostigmine soit plus grande avec le glycopyrrolate. Il semble donc que le glycopyrrolate soit supérieur à l'atropine pour contrecarrer les effets muscariniques de la prostagmine.

\section{ACKNOWLEDGMENTS}

The author expresses his gratitude to the surgeons in the University Hospital, Saskatoon for their patience and to the Department of Medical Documentation, Korle Bu Hospital, Accra, for some of the statistical analysis. Thanks is due to A.H. Robins Company of Richmond, Virginia, for the supply of the drugs for study and some additional statistical work.

\section{REFERENCES}

1. WYANT, G.M. \& KAO, E. Glycopyrrolate methobromide - effect on salivary secretion. Canad. Anaesth. Soc. J. 21(2): 230-241 (1941).

2. Ramamuhtiry, S., Ylagan, L.B., \& WinNie, A.P. Glycopyrrolate as a substitute for atropine: a preliminary report. Anaesth. and Analg. Current Researches 50(5): 732736 (1971).

3. Wyant, G.M. \& DobkIN, A.B. Antisialogogue drugs in man. Anaesthesia 12(2): 203-214 (1957).

4. Ramamurthy, S., Shaker, M.H., \& Winnie, A.P. Glycopyrrolate as a substitute for atropine in neostigmine reversal of muscle relaxant drugs. Canad. Anaesth. Soc. J. 19(4): (1972). 